\title{
THE CALCUTTA KERANI AND THE LONDON CLERK IN THE NINETEENTH CENTURY
}

This book examines the location and representation of the colonial clerk, or the kerani, in the cultural and social space of nineteenth-century colonial India. It provides a comparative history of the clerk in Calcutta vis-à-vis the clerk in contemporary London in order to understand the manifestations of modernity in these two disparate but intimately related spaces.

The volume traces the sociohistorical life of the clerk in the newly emerged city-space of Calcutta and reveals how the Bengali kerani became a complex and distinct figure of bureaucratic and colonial modernity. It analyses the techniques of surveillance and ethical training given to the native clerks and offers insights into the role of education in the production and dissemination of knowledge and hegemony in the colonial setting. The author, through a reading of clerk manuals, handbooks, and literary representations, highlights the class and cultural identity of the English-educated colonial clerk in the new city-space. He also focuses on the ambivalence and unreliability of the clerk, or colonial babu, who became complicit and gave legitimacy to the empire while personifying a complex modernity in the networks of the colonial administration.

This book will be of great interest to students and researchers of colonial and imperial history, literature, cultural studies, city studies, British studies, area studies, commonwealth studies, and South Asian studies, particularly those interested in colonial Bengal.

Sumit Chakrabarti is a professor of English at Presidency University, Kolkata, India. 
$\because$ Taylor \& Francis

Taylor \& Francis Group

http://taylorandfrancis.com 


\section{THE CALCUTTA KERANI AND THE LONDON CLERK IN THE NINETEENTH CENTURY}

Life, Labour, Latitude

Sumit Chakrabarti

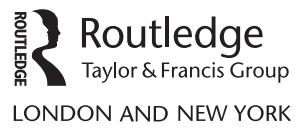


First published 2021

by Routledge

2 Park Square, Milton Park, Abingdon, Oxon OX14 4RN

and by Routledge

52 Vanderbilt Avenue, New York, NY 10017

Routledge is an imprint of the Taylor \& Francis Group, an informa business

(C) 2021 Sumit Chakrabarti

The right of Sumit Chakrabarti to be identified as author of this work

has been asserted by him in accordance with sections 77 and 78 of the Copyright, Designs and Patents Act 1988.

All rights reserved. No part of this book may be reprinted or reproduced or utilised in any form or by any electronic, mechanical, or other means, now known or hereafter invented, including photocopying and recording, or in any information storage or retrieval system, without permission in writing from the publishers.

Trademark notice: Product or corporate names may be trademarks or registered trademarks, and are used only for identification and explanation without intent to infringe.

British Library Cataloguing-in-Publication Data

A catalogue record for this book is available from the British Library

Library of Congress Cataloging-in-Publication Data A catalog record for this book has been requested

ISBN: 978-0-367-14572-9 (hbk)

ISBN: 978-1-003-09469-2 (ebk)

Typeset in Sabon

by Apex CoVantage, LLC 
FOR SUBIR DATTA

FRIEND, MENTOR, TASKMASTER 
$\because$ Taylor \& Francis

Taylor \& Francis Group

http://taylorandfrancis.com 


\section{CONTENTS}

Acknowledgements

viii

Introduction: tracing a genealogy

1 The social and cultural location of the kerani in the empire

2 The clerk in British India: a short survey of the life of the Calcutta kerani

3 The life and times of the London clerk: necessary perspectives

4 The sahib writer in Calcutta: a different discourse 88

5 From manuals to manifestos: discipline and agency

6 Writing clerks, clerks writing: representations in literature

7 The significant omission: the female clerk

Conclusion

Bibliography

Index 


\section{ACKNOWLEDGEMENTS}

For an academic who has generally loved his classroom more than his writing desk, the idea for this book had been sitting in my mind for a while before I could bring myself to put pen on paper. I should perhaps thank Professor Sambudha Sen for a cutting remark and then a gentle suggestion that an essay I had written on the Calcutta kerani had in it the possibility of a book.

It was only when I began with the work that I realized both the paucity and the scattered nature of materials that I had to collate before I could begin to write. This book would not have been possible without the generous grant of the Faculty Research and Professional Development Fund provided by my employer, Presidency University. This fund helped me to visit libraries and archives across the globe for material that I used to write the book.

I am grateful to Adnan Malik from the South/Southeast Asia Library at the University of Berkeley, US; Barbara Roe and Kevin Greenbank (archivist) at the Centre of South Asian Studies, University of Cambridge, UK; Claire Welford-Elkin (Rare Books Superintendent) and members of staff at the Cambridge University Library, UK; the staff of the British Library, London, UK. Without their generous help and support, this book would not have been written. Back home, Bidisha Chakraborty and Sarmistha De at the State Archives of West Bengal were generous with their help. I also begrudgingly acknowledge the help I received from the National Library, Calcutta. It was often a difficult journey. I remain grateful to Arijit Dutta Choudhury, the director general of the National Library, for his help and support. A special note of thanks to Rosinka Chaudhuri for generously permitting me the use of the library and archives at the Centre for Studies in Social Sciences, Calcutta. I also thank all the staff members of Presidency University Library for their continuous help. I especially acknowledge Mrinmoy Mukherjee, who discovered books and documents for me from unknown corners and forgotten shelves.

I warmly acknowledge the help and support of my colleagues at Presidency University: Anupama Mohan, who always inspired me to write, and Souvik Mukherjee, who has always amazed me with his spirit of enquiry. 
Resourceful and ever eager to help, he would keep sending me articles, book chapters, newspaper clippings, and archival material. It was the sheer joy of research and the spirit of fraternity that I discovered in this colleague of mine: Soumen Mukherjee, from the Department of History, one of the earliest readers of my manuscript. A meticulous scholar and a learned colleague, I have benefited immensely from his observations and input. I also acknowledge the generous help of Arpita Mukhopadhyay from Burdwan University. Biswajit Ray from Visva-Bharati University was a constant comrade and would untangle difficult knots during the writing process.

Nikhil Sur, whom I met briefly, was an inspiration. A quiet scholar and an untiring scavenger for new material on nineteenth-century Bengal, he would always hide his immense scholarship behind his unassuming personality. Such scholars are rare, and I hope he reads my work.

It is not easy to afford research assistants in this part of the world. But I had a sincere and interested band of students who saw me through difficult periods. No word of acknowledgement is enough for Soham Deb Barman, student and comrade, who generously offered to copyedit the entire manuscript and set it to stylesheet requirements. Sourav Chattopadhyay, scholarly undergraduate, was always ready to find a book or an article that would help an argument. Anashya 'Ruru' Ghosal would send me material from faraway Cambridge, even if I asked for them at ungodly hours. Simool Sen from the Department of History at Jadavpur University also extended his generous support.

I am grateful to Professor Gautam Bhadra for having taken a lively interest in the process of writing of the book. He meticulously went through some of the chapters, issued suitable and strong reprimands, and opened newer worlds of thought every time we met to discuss the book. He was kind enough to lend me books from his personal library and called regularly to register my progress. I cannot say how grateful I am to him. Professor Swapan Chakravorty is my guru forever, who also read large parts of the manuscript and offered new insights and valuable suggestions. Every discussion with them was humbling and a learning process.

This book is dedicated to Subir Datta. It was in his study that most of the ideas that went on to form the book germinated. Always the first reader and the foremost critic, he has been a part of this book like no one else. We have fleshed out every idea together, and he has suffered all my insecurities and apprehensions. This book belongs to him.

Last, but not the least, I thank my wife and companion, Nandini, whose comradeship I cannot overemphasize. Simply put, I was able to write the book because she was there.

I also thank the anonymous reviewers of the manuscript for their valuable suggestions. The journey with Routledge has been wonderful, and I thank Shashank Sinha, Antara Ray Chaudhary, and Shloka Chauhan for being patient with me and for carrying the project through. 
$\because$ Taylor \& Francis

Taylor \& Francis Group

http://taylorandfrancis.com 


\section{INTRODUCTION}

\section{Tracing a genealogy}

In this book, I have attempted to write a cultural and social history of the kerani, the ministerial office staff of native origin, in nineteenth-century Bengal, first under the rule of the East India Company and subsequently under the direct control of the imperial government. I have used the comparatist mode, trying to read the location and the representation of the kerani in Calcutta vis-à-vis the clerical worker in contemporary London, trying, in the process, to understand the manifestations of clerical modernity in these two disparate but intimately related spaces. The debate has been placed in a narrative of history and its various epistemological tropes of modernity, colonial modernity, the premodern, and the early modern, but the argumentative lens has been trained primarily on the social and literary cultures of the time. The narrative has moved through the historiographical mapping of an emergent site of modernity entrenched in a dynamic of colonialism, trying to fine-tune the consequent reading of culture, occasionally taking recourse to new historicist strategies to get a better perspective on the space of analysis. The occasional literary references, and a full chapter dedicated to literary readings, emerge from my training in the literature classroom, although I believe that I have still left much unsaid on this particular subject.

There is a considerable body of work on nineteenth-century Bengal, including the general historical analyses of an interesting period in the history of Bengal, the emergence of the sciences and reassessments of the history of medicine, cultural and social reorganizations, minor histories of class and gender, popular culture, and literary taste. There have been serious engagements with the lives of major political, literary, and cultural figures-those instrumental in engendering important upheavals in the cultural logic of the times. Although many of these narratives have referred to the figure of the kerani in passing, none of them has comprehensively engaged with him or tried to write a history of the crucial role that the kerani played in a fraught sociocultural space in nineteenth-century Bengal. My initial interest in the subject was incited through this realization of the absence of the kerani figure in almost all major discourses of the time, although they clearly played a pivotal role in the administrative apparatus, as is evident in 
the proliferation of documents during British rule in India and what I have called its managerial modernity. In a recent book on the subject of documents and scribal culture in nineteenth-century Madras, Bhavani Raman (2012) calls this a government by writing:

The government by writing installed under colonialism stemmed from the East India Company's peculiar 'corporate sovereignty'. From its very inception in the seventeenth century, the British East India Company's political dominance was forged by the sword, built on the spine of the accountant's ledger, and held together by written correspondence.

(pp. 8-9)

The role of the kerani in Calcutta was therefore not one that could be easily overlooked. However, neither in literature nor in the historical-cultural discourse has there been any comprehensive attempt to write about the kerani life of nineteenth-century Calcutta. This book is an attempt both to trace the sociohistorical life of the kerani of that period and to examine the reason for this interestingly conspicuous absence.

\section{The organization of this book}

In the first chapter, the presence and the location of the kerani in the newly emerged city-space of Calcutta is examined. The chapter tries to explore and understand how Calcutta as a city, born directly out of administrative and business needs, was essentially different as an urban space compared to such older and more generically evolved urban spaces as Dhaka or Murshidabad. In it, I try to understand the class identity of the kerani in this parvenu commercial space of a new city where the emergence of the middle class was somewhat unlike other, older urban milieus. I determine, in this context, whether the kerani could be called a bhadralok and whether his location could be read in the current associations of bhadraloki.

Still trying to fit the kerani in the cultural logic of the city, the second chapter focuses on the life of the kerani in the city-space, attempting to read his daily life and everyday existence as markers of identity formation. The chapter discusses the nature of English education and its ramifications on kerani life, his salary, and living conditions, from evidence in government reports and commissions and read through a postcolonial lens.

The second chapter also examines whether the kerani is a better fit to being a babu or a bhadralok, or neither. It also looks into whether the gradually emergent participatory logic of colonial modernity kept the kerani out of its prescribed fold of the 'educated middle class'.

The third chapter initiates the comparatist mode by trying to read kerani life as offset by the life of the contemporary clerk in London. The chapter 
traces the trajectory of the gradual modernization of clerical practice from the Dickensian counting house to the modern office in nineteenth-century London, and it includes important debates on class identity, differences between the salaried clerk and the waged labourer, and whether the clerk was a gentleman. This chapter is used as a crucial counterpoint to read the life of the Calcutta kerani through a comparative lens and situate the question of his representation in a complex debate on modernity and colonialism.

The fourth chapter complicates both of the preceding questions of modernity and colonialism by examining the presence of the British writers (ministerial staff) in nineteenth-century Calcutta. An analysis of their extravagant social lives and irresponsible professional lives unsettles the modernity debate and underscores the fraught nature of clerical modernity, which refuses to be defined by either racial or geographical classificatory modes. Neither the lowly clerk in London nor the indigenous kerani in Calcutta could have anything in common with the curiously anachronistic figure of the writer in colonial Calcutta.

In the fifth chapter, I attempt a close reading of some of the clerk manuals and handbooks, published either in London or in Calcutta, to examine the commonalities of techniques of surveillance and ethical training that was considered to be an intrinsic part of clerical training in Victorian England and its colonies alike. I try to understand whether there were significant differences in the model code of conduct for clerks in the two spaces, where the dynamics of power were significantly different. This chapter discusses the rise and proliferation of organs and journals in England that lent a voice to the clerical workforce in the nineteenth century, clearing a space for counterdiscursive possibilities in an otherwise-panoptical space. In the same breath, the chapter discusses the embedded masculinity in such counter-discourse, where the language of the demand for rights is unfailingly that of the man, in spite of the fact that women had already joined the clerical workforce in England. The chapter also talks about how such narratives of dissent were still an impossibility in the colonized space.

The sixth chapter examines the contemporary literature on clerks, both in London and in Calcutta. Literary tracts were written both about and by the clerks. In it, I try to understand whether it is possible to trace a commonality of representation in both the early and the late-Victorian delineation of the character of the clerk in London on the one hand and the possible similarities of the London clerk with the Calcutta kerani of the nineteenth century on the other.

The seventh chapter briefly addresses the question of the female clerk in London, arguing that the comparatist model becomes redundant here, because women in Calcutta was still a few years away from a working life. This book may thus be seen as an attempt of a scholar of literature to write a cultural history of the Calcutta kerani in the nineteenth century as refracted through the lenses of the colonial/postcolonial debate and the debates on modernity. 


\section{The genealogy: scribal practices of the immediate past}

Throughout the book, I view the figure of the Calcutta kerani of the nineteenth century as a new entrant into the narrative of cultural and professional history. I suggest that the Calcutta kerani belonged nowhere and came from nowhere. The kerani has been read as a figure of lack who was born out of the peculiar necessity of colonial and imperial governance, born in situ, purely for the purpose of lowly clerical work, and dispensable at no peril to his employer. The Calcutta kerani, as I have seen him, did not have a tradition of scribal practice to fall back on, was not trained in specialized disciplines that had a prescribed body of texts, and was not following a trajectory of ancestral continuity that could suitably be used as reference in his work. I claim for the kerani in nineteenth-century Calcutta a unique place in history, bereft of a past, not claiming any agency of tradition, existing like a phoenix, a perpetual marker of ambivalence in the face of identitarianism and historicist traceability. I have consciously called him the kerani throughout the book and never used the word 'scribe' for him.

In an important essay written on scribal practice and culture, Muzaffar Alam and Sanjay Subrahmanyam (2010) referred to scribes in the Mughal period as clearly belonging to a middle or a professional class (p. 395). They further argue that the eighteenth century was the century of the scribe in South Asian history:

Scribes had existed long before, and scribes would exist afterward, even with the advent of print; but in this century, they came-more or less everywhere in the sub-continent-to take on a truly protean quality, using their scribal profession as a point of departure to embark on the conquest of a number of new horizons.

(Alam \& Subrahmanyam, 2010, p. 395)

The person of this scribe, variously called the secretary, the interlocutor, the spokesperson, or the accountant, was deeply implicated in the politics of the eighteenth-century court. Sometimes the umbrella term munshi has been used for them, although, as Alam and Subrahmanyam (2004) claim, the term munshi 'has shifted semantically over the years' (p. 61) and eventually acquired the meaning of 'pundit' or 'teacher' in the mid nineteenth century. In the initial years of Company rule, the munshi (in the older sense of the term) used to play a crucial role in matters of administration:

The real interlocutor for the Company official ... was the munshi, who was mediator and spokesman (vakil), but also a key personage who could both read and draft materials in Persian, and who had a 
grasp over the realities of politics that men such as Warren Hastings, Antoine Polier, and Claude Martin found altogether indispensable. (Alam \& Subrahmanyam, 2004, p. 61)

The munshi was thus not merely a writer but an interlocutor and an interpreter as well. Well versed in the politics of the times, they often acted as agents of the native government and had the agency of states, persons or diplomats in crucial political negotiations. Christopher Bayly (1996) writes,

The most dynamic social formation of the period was not a class defined in a simple economic sense, but the writer's office (munshikhana) whose members combined respectable status with access to the charisma of writing. These people, although dependent and humiliated, were to play an important part in the establishment of British rule.

It is not difficult to trace a genealogy of these munshis, most of whom came from Hindu clans of kayasthas and khatris and often brahmins as well. They were all well trained in Persian language and literature and joined the Mughal court as various kinds of ministerial workers: mutsaddis, muharrirs, bakshis, and munshis. Most of them either hailed from a family of educated scholars and statespersons or were beginners of a lineage of philologists, poets, grammarians, or commentators. Celebrated among them were Harkaran Das, Chandrabhan 'Brahman', Madho Ram, Sujan Rai, Bhupat Rai, Anand Ram 'Mukhlis', and Bindraban 'Khwushgu':

From the middle of the seventeenth century, the departments of accountancy (siyaq), draftsmanship (insha), and the office of revenue minister (divan) were mostly filled by ... Kayastha and Khatri munshis and muharrirs.... Selections and specimens of their writings formed part of the syllabi of Persian studies at madrasahs. They produced excellent works in the eighteenth century in the philological sciences: the Mir'at al-Istilah of Anand Ram 'Mukhlis', the Bahar-i 'Ajam of Tek Chand 'Bahar' and the Mustalahat al-Shu 'ara' of Siyalkoti Mal 'Varasta' are among the most exhaustive lexicons compiled in India.

(Alam \& Subrahmanyam, 2004, p. 62)

It is not difficult to imagine that this world of munshis of the seventeenth and eighteenth centuries that I am deliberating on here was far removed in every manner of imagination from the quotidian world of the common kerani in nineteenth-century Calcutta. Although, apparently, the kerani was 
doing the same kind of work as the munshi in the Mughal courts-those of drafting ability and accountancy-the nature of their social or political influence belonged to entirely different worlds and perspectives. In a letter written to his son Khvajah Tej Bhan, the celebrated munshi Chandrabhan 'Brahman' lays down some of the basic tenets of being a perfect munshi. He advises his son to first be acquainted with the Mughal system of norms (akblaq) by studying the Akblaq-i Nasiri, Akblaq-i Jalali, Gulistan, and Bustan, some of the foundational texts on the subject. He insists on the importance of coherent drafting and good calligraphy. He also urges Tej Bhan to learn accountancy (siyaq) and scribal skills (navisindagi). He emphasizes the importance of books on norms, ethics, and history, such as Habib al-Siyar, Rawzat al-Salatin, Zafar-namah, and Akbar-namah, among others. Chandrabhan also tells his son to read the master poets so that he will acquire the skill of elegant language that will stand him in good stead in the company of the learned (for a detailed content of the letter see, Kinra, 2015, pp. 60-64). Alam and Subrahmanyam (2004) write on the elaborate reading list that Chandrabhan passes on to his son as necessary training for becoming a good secretary:

The extensive list . . . is remarkable both for its diversity and programmatic coherence. The list begins with texts on statecraft and moralia, touches on the question of accountancy and epistolography, then moves quickly to a set of histories and chronicles, before ending with an extensive list of poets both old and new ... many Hindu scriptures and other Indic texts were rendered into Persian, and these too joined the cultural accessories of the typical Kayastha or Khatri.

The kayastha or khatri caste, and occasionally the brahmin, were the typical professional accountants and recordkeepers of the Mughal court. Evidently, family lineage and training were matters of utmost importance in the selection and subsequent career graph of these munshis. Most of them came from families of munshis or bakshis who had an elite class of patrons and were respected and wealthy courtiers. They were invested as intellectuals in the administrative system trying to develop a tradition and mode of engagement through received knowledge and the political contingency of the period. By the late seventeenth century, 'these newly arrived scribes and intellectuals were feeling sufficiently confident of their position to propose changes in received models of history-writing and new framings for old histories' (Alam \& Subrahmanyam, 2010, p. 420). In fact, although many of them were masters of technique, rules, and accounts, some of the more celebrated munshis engaged philosophically with questions of governance. One of 
them was Nik Rai, about whom Alam and Subrahmanyam write at the end of their 2004 essay:

The philosophical universe within which he conceives of all matters-including issues of social and religious conflict-is impregnated with Persian, and with all the richness of the 'secular' tradition that Indo-Persian represented by the seventeenth century. It is in this sense that we must understand what it meant to become, and to be, a munshi in the later Mughal world.

Evidently, with the gradual consolidation of Company rule, and later under the British Empire, the emergence of a discourse of managerial modernity led to the inevitable decline of this tradition of scribal scholarship and culture. British rule naturally followed its own narrative of modernity, based on the model of a corporate understanding of administration that was stratified on the basis of more-clearly defined power structures and more professional relationships. The gradual transformation of the nature of work and the meaning of the word munshi is symptomatic of this change in the nature of governance. The transformation from the feudal to the corporate power structure led to the systematic devaluation of the system of patronage that provided necessary security to the tradition of secretarial practice and led them to become scribes and scholars at the same time. In many cases, the munshi now became a teacher, mostly of Persian, and his important role in administration gradually became a thing of the past.

The kerani of nineteenth-century Calcutta belonged to a different universe, far removed from the hallowed world of these celebrated munshis. The chba-posha kerani (the kerani who is only good at breeding children) or the macchi-mara kerani (the kerani who swats flies in the office having nothing better to do or someone who kills a fly and sticks it to their copied text as there was a dead fly in the original text-that is to say, a mechanical and unthinking copier) as he was had no claims to such tradition, education, or wealth as the munshis of the Mughal courts. Although mostly belonging to the upper castes, the typical caste identity of the kaysatha or khatri or brahmin as the professional kerani with a lineage and tradition was not particular to the Bengali kerani in the nineteenth century. Most of them were keranis by chance, not by choice or family lineage. The selection of keranis was mostly random, and they formed a dispensable part of the administration, with many qualified candidates vying for the job of this lowly functionary of colonial administration. As the book will make clear, there was almost no prestige or social value attached to the job of the kerani in colonial Bengal.

It is crucial to understand why and how this shift in the nature of scribal practice happened in the first place. Bhavani Raman (2012) makes an 
important point in her book on administrative practices of the British East India Company in the Madras presidency in the nineteenth century:

From the late eighteenth century, the Company instituted a government of writing under parliamentary pressure to perpetuate the mastery of the Indian subcontinent for the metropole's finance and manufacturing empires.... The Company's bureaucratic state coincided with a time when the conceptual term 'bureaucracy' acquired currency as a powerful organizational form of office holding, expertise, corporate management, and rule-based government. Continuous writing in these years became the idealized solution to the problem of managing trust and reliability across distance.

(pp. 2-3)

In this book, I term this process 'managerial modernity'. The bureaucratic temper of the administration led them to import forms of modernity from the metropole, and the act of writing was one of them, a process of systematic documentation of every administrative action that would help the colonizer comprehend the newly acquired space on the one hand and act as a form of surveillance technique on the other. This required a regular supply of clerks or keranis with basic training in accounts and language to handle the simplest of bureaucratic chores but apparently with little comprehension of the motives of surveillance and control. Raman calls it papereality, 'the exclusive reliance on official written documents to represent the world' (Raman, 2012, p. 3). The kerani thus occupies a contingent space, marked on the one hand by his dispensability and on the other by his agency as the subject that prepares the document. The iterable qualities of writing and the micro-practices of documenting that gradually developed across the colonized space makes the kerani a crucial figure, ambivalent and unreliable, in many ways unlike the scribe of the past. The kerani, I argue in this book, is therefore distinctly a product of European colonialism. His predecessor was unlike him and, in fact, belonged to a different cultural paradigm. As Raman (2012) writes,

The story of the colonial clerk or babu is intimately braided with the historical problem of how a small group of Europeans established everyday control over a vast colony with the assistance of native subordinates. It is thus that the collaborating babu, the infamously complicit Indian clerk, serves as an iconic metonym for a split modern subjectivity birthed by colonial ledgers, the English language, and European-style schools.

The kerani figure that I have taken up for analysis in this book is contingently born at a crucial juncture in the history of colonialism, bereft of a 
past, and complicit in the papereality of the empire, in a network of an incomprehensible modernity and hanging from the fringe of every possible representation.

It is possible to argue that in spite of certain basic similarities in job description and patterns of service, an attempt to compare the kerani with the upper-class munshi of the Mughal courts is tenuous and unnecessary. In terms of class identity, financial status, conditions of employment, training, and lineage, the scale of comparison will be untenable. The munshi was never in the kerani's league. While it is imperative to trace a genealogy of native scribal tradition, one cannot totally disagree with such a contention. However, even among his contemporaries in other parts of India, such as the presidencies of Bombay or Madras, the Bengali kerani stands out in certain ways as a uniquely ahistorical subject of history. In nineteenth-century Bombay, for example, most clerical jobs were monopolized by the brahmans and the banias, although lower-caste clerks were also not unknown. However, the best-paid clerical jobs were in the hands of the prabhus, who could claim a certain lineage in the profession:

In the beginning of the seventeenth century, when the English settled as traders in Surat, they found Prabhus established as clerks to the Portuguese, and ever since then Prabhus have from their readiness to learn English, their honesty, and a certain freedom of customs and dignity of manner continued to be liked and trusted by the English.

(Hindu Clerks, 1879 , p. 5)

Although not as powerful as the prabhus of Bombay, even the lowly scribes of Madras, the karanam (or the kanakkuppillai) had their own set of skills quite unique to their profession. Writers of Persian, Telugu, or Modi scripts, they would use palm leaves (olai), and their origin may be traced to the Pallava, Pandya, and Chola dynasties of the past:

The textual tradition that flourished around palm leaf was restricted to a small circle of stylus wielders and prized the ability to reciteparticularly to recite from memory. Prosody, poetics, and grammar were taught along established teacher-disciple lineages.

(Raman, 2012, p. 12)

That is to say, many of these lowly indigenous scribes had at least some specialized skill sets that played a role in their choice as clerks of some kind in the empire. Moreover, both Bombay and Madras were older city-spaces than was Calcutta, and thus, it was possible to trace a tradition of training even among the lowly scribes of these places. It is perhaps the fact that Calcutta was a new urban space and that most people who came for professional 
reasons, or otherwise, to the city in the eighteenth and the nineteenth centuries were a category of fortune seekers, intermediaries, businesspeople, or service providers of random disposition that makes it not possible to trace a tradition of the keranis of various kinds, even if they had any. Their choice as keranis was as random as their presence in the city, and it may be said that the subject position of the Calcutta kerani was perhaps more individualized than that of clerical workers in other, more ancient urban spaces. In this book, I try to examine this subject position of the kerani in nineteenthcentury Calcutta, one that was unable to appeal to a collective set in the past or claim for itself the authenticity of a cultural narrative embedded in a premodern past.

\section{Trying to trace a genealogy in Bengal: a literary exploration}

Before I try to trace a genealogy of the kerani in Bengal, I briefly deliberate on the etymology of the word 'kerani'. The idea of clerical labour had various natures in Mughal or Muslim Bengal, or what we may call premodern Bengal. Thus, the English umbrella term 'clerk' would incorporate in its fold different types and levels of clerical workers in a pre-industrialized or a premodern economy belonging to categorically different professional spheres, such as the court, the revenue office, or the collectorate. The munshi, the muharri, the vakil, the duftaree, the tehsildar, the mamlutdar, the sheristadar, the poddar, the nazir, the gomosta, the mutsaddi, the nakalnabish, the khasnabish, and so on were all therefore doing clerical work, and in many cases, these nomenclatures were retained by the colonial administration. The list of such workers will seem endless, and their duties and responsibilities often overlap and have minor functional differences. 'Kerani' seems to be a new entrant in the lexicon of Bengali words and does not seem to have been much in use in Mughal Bengal. Into the nineteenth century, William Carey's Dictionary of the Bengalee Language (1828) still gives the meaning of the word 'clerk' as a munshi or a muharrir (p. 62). Ram Comul Sen's Dictionary in English and Bengalee, published in 1834, also translates the word 'clerk' as advisor, muharrir, writer, nakalnabish, or mutsaddi (p. 158). It is only in the later dictionaries of the Bengali language that one finds the word 'kerani'. Jnanendramohan Das, in his dictionary Bangala Bhasar Ovidhan (1917), traces the route of the word 'kerani' or 'kyarani' to the word 'kanni' in the Sunyapurana. However, he also notes that the word was used to describe Eurasians or firanghees after the arrival of Europeans in Muslim India. He also incites the possibility of the word being derived from the Portuguese word for clerks: 'escrevente'. Thus, Jnanendramohan Das leaves both the root and the meaning of 'kerani' ambiguous. Haricharan Bandopadhyay, in his Bangiya Sabdakosh (1934/1966), also refers to both the words 'kanni' (Sanskrit) and 'escrevente' (Portuguese) as the possible roots of the word 
'kerani' (p. 677). Interestingly, he clearly asserts that a kerani is a writer in an 'English office' (p. 677), thereby indicating towards a postcolonial use of the word in the Bengali language. However, both Jnanendramohan and Haricharan refer to the Sanskrit word 'karan' as a possible root of the word. The word 'karan', though, is multilayered and has multiple meanings, including the writer, the calligrapher, the body, the site, the kayastha caste, and others, which would lead to a complex philosophical deliberation on the many possible meanings of the derivative word 'kerani'. Most of the writers, editors, and compilers of dictionaries have either maintained an ambiguous root for the word kerani or have simplified it to simply mean 'clerk'. Some dictionaries, such as the Samsad Bangla Ovidhan (1964), have also used the word 'karanik' as the meaning of kerani (p. 191). Both the words can possibly be traced back to the Sanskrit root 'karan', although neither Jnanendramohan nor Haricharan have referred to 'karanik' as a meaning for 'kerani'. Nor is there any linguistic or grammatical basis of connecting the two words. However, in bureaucratic and popular Bengali parlance, the words 'kerani' and 'karanik' are sometimes used interchangeably.

On the subject of the milieu of nineteenth-century Calcutta, from which the kerani hailed or emerged, it may be said that there was considerable deliberation on the idea of a job or chakri. The word 'chakri' has inevitable connotations of being a chakor or a servant. On the one hand, having a job meant both a steady salary and a sense of security; it also had the accompanying implications of servitude and lack of freedom or agency. Such a pejorative implication was further complicated by the question of subjection to a colonial power. Having a chakri, therefore, implied a kind of double subjection: the native subject was already under colonial rule; serving the Company or the government meant another set of compulsory directives. On the other hand, exposure to enlightenment modernity opened up a different universe for the English-educated bhadralok. For him, this meant a continuous refashioning of the self through exposure to a new form of textual culture, and ideas of nationhood, nationality, dissent, and subversion gradually acquired currency and redefined earlier notions of sovereignty, consciousness, and selfhood.

The Bengali bhadralok of the nineteenth century was caught in the web of a veritable mélange of influences, each of which qualified the other in a confluence of discourses. His English education opened up for him a range of texts, culturally alien, but invested with enlightenment ideas that influenced him considerably; his idea of the self and selfhood were churned by the narratives of modernity; the idea of nation and nationalism formed another important strand of dissent that was nurtured in a separate but related discourse of colonial modernity; a sense of the past and a revival of traditionalist notions of identity was a narrative stoked, curiously, by his exposure to Western education. While the different formations of modernity incorporated into native discourse by the colonial master redefined notions 
of education and culture, it was through this exposure that narratives of dissent were also foregrounded by the Bengali bhadralok.

A typical example of such a blend of influences can be found in the character of Neemchand Datta in Deenabandhu Mitra's farce Sadhabar Ekadashi (1866). Neemchand is English educated and is widely exposed to Western literary texts: 'I read English, write English, talk English, speechify in English, think in English, dream in English' (Mitra, 1866/1943, p. 44). However, he refuses any form of chakri, is a drunkard, and is sheltered in the house of a relative. The implications of Neemchand's stance in the play create a complex discourse of meanings which might go on to clear some space for exploring the problematic genealogy of keranidom in the context of Bengal. In the first place, Neemchand is deeply disdainful of the native servant of the imperial government, as is apparent from his behaviour towards Kenaram Ghosh, the deputy magistrate, and his brother-in-law. As he quotes from Othello, 'You are one of those, that will not serve God, if the devil bid you', he asks 'How many Ghotiram deputies like you are there?' (Mitra, 1866/1943, p. 43). He calls Kenaram a 'kyabla hakim', or an unsmart magistrate, and expresses deep suspicion about both Kenaram's intelligence and command of the English language. This is a complex moment in the play. In the same breath, Neemchand celebrates the liberal humanist aspect of Western education by quoting Shakespeare and critiques the native for succumbing to the snares of a job offered by the colonial master. His liberal education and the subsequent faith in the ideas of freedom and nobility (he refers to both these qualities in the play) contradict the notion of servitude symptomatic of the native keeping a job with the colonial administration. Kenaram becomes, for him, the representative of the servile native who succumbs to the humiliating trope of subservience by accepting the chakri doled out to him by the white master. Paradoxically, the Western-educated and English-speaking liberal Neemchand draws on the past glory of the kayastha clan as a counternarrative to the meek submission of the likes of Kenaram. He refers to the story of the five brahmans and five kayasthas visiting the court of King Adisura of Bengal. Both the castes were hierarchically similar. However, as the king asks the kayasthas about their relationships with the brahmins, all of them except one admitted to being the bhritya (servant) of the brahmins. Only the representative of the Datta clan (whom Neemchand considers to be his rightful predecessor) refuses servitude to the brahmin and declares, 'Datta karo bhritya noy' [Datta is no one's servant] (Mitra, 1866/1943, p. 52). However, this claim to the historicity of the Datta identity that Neemchand makes is not historically tenable. The brahmins and the kayasthas who came to the court of Adisura hailed from either Kanauj or the south of India and hence were not Bengalis. In an informed study of the kulajigranthas (documents on lineage) of the times, Dineshchandra Sarkar (1982) talks about the varying accounts of this event and its historical unreliability (pp. 137-138). However, there is no doubt that neither the brahmins nor the kayasthas were of Bengali 
descent. In a succinct discourse on the subject of Neemchand's allusion to the event, Biswajit Ray in his 2002 essay complicates this further by bringing in the predicament of the author of the play into his analysis:

\begin{abstract}
Neemchand doesn't have a job. In Adisura's court Ghosh had admitted to being the brahmin's servant, but Datta did not admit to servitude. Whereas, in the nineteenth century the jobless Datta, Neemchand, stays in his brother-in-law Kenaram's house. . . . By virtue of his Western education Neemchand was able to identify the 'independence' of the Datta in Adisura's court; while, in spite of having to bear insults, the creator of Neemchand, Deenabandhu Mitra, had to keep his job with the very imperialists who had brought Western education to the native.
\end{abstract}

Ray (2002/2010) also brings in the case of brahmin Deputy Magistrate Bankimchandra Chattopadhyay and the character Kamalakanta Chakrabarty (another brahmin) into his analysis (pp. 14-15). While Kamalakanta loses his job as a kerani, his maker, Chattopadhyay, has always kept his job. Likewise, although Neemchand does not have a job, his maker, Mitra, is a postmaster-general with the imperial government. Ray writes, 'Bankim was a brahmin, Deenabandhu a kayastha. In earlier times they would have led comfortable lives by virtue of their caste identity (jatikaulinya). But in times of the supremacy of capital, maintaining a job was the only solution' (p. 14).

This intervention by Ray opens up multiple strands of this complicated debate. In the first place, it is evident that administrative jobs were not traditionally related to caste identity in Bengal, unlike in many other parts of the country. The subservient kayastha figure from the past, ready to be employed by the brahmin, is undercut by the Datta figure, who refuses to serve under anyone. Neemchand ahistorically revives that resistant figure of the Datta to justify his refusal to have a job. However, he shows off his pride as a 'Datta' and not as a kayastha. His disdain for the deputy magistrate is based not on caste identity but on how he imagines himself to be the descendant of that singular Datta at Adisura's court. He uses this agency merely to undermine the chakri of his brother-in-law. If the native deputy magistrate is a figure of ridicule for Neemchand, it is not difficult to imagine his opinion of the kerani in a similar context.

If one were to briefly digress and examine the literature of Bengal from the earlier centuries, the genealogical mapping of a consistent scribal practice would not be consolidated either. The kayasthas in Bengal, for example, are not depicted as a community of scribes, although it is possible to find an occasional individual. One of the most talked about figures of a possible scribe is Bhnaru Datta, who appears in Mukundaram Chakrabarty's sixteenth-century text Kabikankan-Chandi or in the Chandimangal, written 
in the tradition of the mangalkavyas. Bhnaru Datta is distinctly different from the other kayasthas who arrive at the court of King Kaalketu seeking patronage. The kayasthas arrive as a clan (or jati) and claim to be educated bhadraloks who have come to invest the new-found kingdom with the prestige of education and distinction: 'Kono jon siddhokul Keho sadhyo dharmamul/Doshheen kayasther sobha/Prosonno sobhare bani Lekhapora sove jaani/Bhovyojon nogorer shova'. [The kayasthas are erudite and well read in the scriptures, faultless, educated and would be a distinguished addition to the new kingdom] (Chakrabarty, 1579/1962, p. 354). Their claims to erudition and distinction are quite similar to that of the brahmins, who have already staked their claim to a livelihood in Kaalketu's kingdom. Both these castes will invest the kingdom with much-deserved prestige and dignity. Interestingly, although the kayasthas claim education and erudition, there is no reference in the text to prove that they were scribes or that they hailed from any scribal culture.

Bhnaru Datta, a kayastha himself, seems to be clearly separated from his clan. He is dismissed by Kaalketu from his court on charges of betrayal and deception. Bhnaru decides to take his revenge on Kaalketu by instigating the powerful Kalinga king against him. The poet depicts the lonely figure of Bhnaru, separated from his clan but hailing his kayastha ancestors: 'Ekela cholila pothey keho nahi sathe/Horidatter byata hoi, Joydotter naati' [Bhnaru is alone, without a companion, but hails his father, Hori Datta, and his grandfather Joy Datta] (Chakrabarty, 1579/1962, p. 367). Bhnaru Datta dresses up carefully before he arrives at the court of the powerful colonizer, the king of Kalinga: 'Mostoke bandhilo pag nahi dhake kesh./Mrittikar tilok koilo ronjit koilo besh./Koifiyoti pnajikhaan nilo sabdhane./Sreehori boliya Bhnaru kolom gnoje kaane.' [Bhnaru dons his paagri (traditional headgear popular with keranis), takes his book of rhetoric, and places the pen behind his ear] (Chakrabarty, 1579/1962, p. 368). This is the classic symptom of being a scribe: the headgear, the book of rhetoric and the pen behind the ear. Consequently, the kayastha figure of Bhnaru Datta becomes a classic example in Bengali literary history of the figure of deceitfulness, betrayal, and insincerity. The Bengali kerani could be associated with all these qualities, but that is only incidental. However, when Neemchand has to search for an ancestry of the kayastha-Datta clan, he does not mention the sixteenth-century figure of Bhnaru Datta but instead goes back to the earlier figure of the kayastha who refuses subordination. For the Western-educated and enlightened Bengali male, Bhnaru is perhaps the figure of the native succumbing to a colonial master, while the Datta in Adisura's court is a rebel who refuses subordination. Ironically, though, this Datta was not of Bengali descent.

It is possible to draw a few important inferences from the foregoing discussion. In the first place, it is difficult to establish a direct link between caste identity and scribal culture in Bengal. Also, as evident at least from the Chandimangal, the kayasthas as a clan did not claim scribal practice as a 
major profession, although they belonged to an educated class of gentlemen. Also, even if Bhnaru Datta is admittedly a scribe and a kayastha, he is clearly separated from the rest of his clan and stands as a singular figure of cunning and disruption. Also, other than his attire, there is no other reference in the text to prove his scribal identity. Nor do the kayasthas arriving at King Adisura's court lay any claim to scribal practice. Thus, the link between a caste identity and scribal practice that could easily be established during the Mughal period in north or western India, or later on in the south of India, is generally absent in the case of Bengal. Moreover, nineteenth-century Calcutta was a conglomerate of people from myriad social and caste orders, and the emergence of the kerani figure had a randomness that belies any castebased classification. The creation of characters such as Neemchand Datta or Kamalakanta Chakraborty was symptomatic of a confused reaction to the novelty of a professional life that could be censured by a reference to the past, though accepted by the contingency of the present. My contention here is to suggest that the figure of the kerani in nineteenth-century Calcutta was an arbitrary but necessary presence, whose lineage could not be traced to traditional scribal practice, and that there was considerable ambiguity in the bhadralok profession. Both Neemchand and Kamalakanta, educated and upper-caste elites, render expression to this ambiguity.

\section{Is the kerani a subaltern? A necessary question}

In the larger scheme of postcolonial historiography and the representation of the marginal figure in history, the question of subalternity and its complex relationship with forms of modernity has been an important discussion. Much humanities scholarship across disciplines in postcolonial India has engaged with the analysis of the subject position of this marginal figure and tried to grapple with forms of representation or the lack of it in the larger contexts of class, gender, and caste. Across the chapters in this book, the nineteenth-century kerani in Calcutta is presented as a marginal figure, caught in interstitial spaces, straddling different identitarian discourses, trying to locate a place of his own in the deterministic structures of history. Therefore, I examine whether it is possible to lay a claim of subalternity for the nineteenth-century Calcutta kerani as a subject of history.

Dipesh Chakrabarty (2000) argues in his essay 'Minority Histories, Subaltern Pasts' that in the discipline of history the act of choosing a subject depends on a certain kind of rationality and a consequent understanding of the 'real' and thereby the 'exclusions are ultimately epistemological' (p. 98). I argue in this book that the many histories and narratives on nineteenthcentury Bengal have either mentioned the kerani in the passing, used him as a humorous aside, or summarily neglected his presence for other matters of greater or more-immediate relevance. The 'real' in the colonial or postcolonial historiography of nineteenth-century Bengal has always excluded the 
figure of the kerani. This exclusion, Chakrabarty argues, is not arbitrary but epistemological, and hence, it will follow that the presence of the kerani as a subject of history will not 'give us rationally defensible principles for narration' (p. 98). No wonder, then, why I see the Bengali kerani in nineteenthcentury Calcutta as an absent presence. Later in the essay, Chakrabarty formulates the reason for the minoritization of certain pasts in the larger rational narrative of history:

Some constructions and experiences of the past stay 'minor' in the sense that their very incorporation into historical narratives converts them into pasts 'of lesser importance' vis-à-vis dominant understandings of what constitutes fact and evidence (and hence vis-à-vis the underlying principle of rationality) in the practices of professional history. Such 'minor' pasts are those experiences of the past that always have to be assigned to an 'inferior' or 'marginal' position as they are translated into the academic historian's language.

(pp. 100-101)

Perhaps my training in literature led me to see beyond the principle of rationality, and its consequent epistemic manifestations; to underscore this absence; and to try to tell the story (if not the history) of the Calcutta kerani. Beyond the supposed inferiority or marginality of the position of the kerani in historical narratives on nineteenth-century Bengal, the near absence of this figure in most cultural critiques on the subject stoked my curiosity. Is it that the understated homogeneity of postcolonial critique, in the choice of its many marginalities, refuses to chart the implicit ambiguities of certain experiences that are epistemologically challenging or suspect?

The fundamental query, then, on the matter of the kerani and the categorization of the subaltern will be as follows: is there a 'denial of consciousness' involved in the question of the subject position of the kerani in the ideological formation of subaltern studies? There have been protracted debates in the subaltern school for the past few decades on whether the subaltern has been invested with enough agency so that they may see themselves as the subject of their own history. The dependence of subaltern studies scholars on the derivative and elite narratives of colonialism, nationalism, or Marxism and their subsequent collusion with the grand narrative of modernity has been a point of discussion in humanities classrooms for decades. The corrective historiography that takes into account the religious and the mythic, or all that is considered premodern or non-modern, has also garnered epistemological sanction over the years. It would seem that the project of provincializing Europe has served as a perfect antidote to all the essentialisms of modernity, and the representation of the subaltern has achieved a political victory of some kind: 
The turn towards the critique of Europe or the West marks the explicit convergence between subaltern studies and 'postcolonial critique'. The subaltern is now presented as embodying differences that frustrate the universal project of modernity.... Subaltern studies, in its postcolonial avatar, insists not on the autonomy of the subaltern domain from that of the elite/dominant, but the subalterns' radical difference vis-à-vis the dominant discourse.

(Nixon, 2019, p. 28)

Postcolonial critique thus foregrounds a kind of radical alterity for the subaltern subject that reorients, in a way, the epistemological rationality at the heart of the disciplinary structure of historiography. It collates 'the rule of historicism and lifeworld/practices of the subaltern which are imbued with the agency of the supernatural and gods' (Nixon, 2019, p. 29), thereby opening up the discipline towards a self-reflexive model and investing it with a notion of arbitrariness. Thus, the peasant, the labourer, the woman, or the dalit, for example, made their way into the dominant discourses of writing in the twentieth century. However, the absence or the expunction of the kerani from most colonial and postcolonial discourses led me to think, in this book, of the possible problem of his placement in a historical-cultural narrative.

The figure of the kerani was a significant, if not dominant, presence in the sociocultural and professional milieu of nineteenth-century Calcutta. Is it possible that this particular professional group was conceived by all forms of community as the 'outside', which led to various degrees of exclusion of the kerani from any form of historical writing? I have engaged with the idea of community and spoken about the assimilationist tendencies of a premodern society in what I have termed a wholesome community. Historians of the subaltern have also engaged with the idea of community and shown how modern regimes of power have foregrounded capital over community as the authentic narrative of progress (Chatterjee, 1994; Nixon, 2019). It was, therefore, an attempt of the subaltern historian to revisit the notion of community and reinscribe it in the practices of history writing: 'Community exists not as a remnant, but as a living entity among the subaltern classes that has been marginalized by the universal narrative of modernity' (Nixon, 2019 , p. 29). I agree with this as an important critique of modernity. However, my contention is to disagree with the easy homogeneity of the classification of the marginal, almost leading the debate towards a closure, where the possibility of other possible representations is quietly forgotten. I am not trying to lead this question of representation towards a postmodern obfuscation, by suggesting innumerable possible subject positions in a particular class formation. However, as I discuss in this book, particularly in the first two chapters, it is not easy to find a fit for the kerani in any set class identity. $\mathrm{He}$ is neither the bhadralok, the babu, nor the working-class proletariat. 
But the absence of a situated and epistemologically discernible class identity does not preclude representation. It seems that the project of subaltern studies, even in its latest avatar, has submitted to the easy binaries of religiosity versus political consciousness, or the archaic versus the modern. The kerani is not the classic subaltern figure, but he has all the possibilities of subalternity. The formulation of the subaltern, in all its radical alterity, it seems to me, has submitted to a carefully designed epistemological trap, which fails to represent the kerani. Therefore, the kerani in nineteenth-century Calcutta will not be a subaltern.

\section{Before the beginning}

In this brief introduction, I tried to enumerate who the nineteenth-century Calcutta kerani is not. Although certain overlaps are inevitable, and similarities germane, none of the foregoing three disparate categories will contain the historical and cultural complexity of the figure of central concern of this book. In the choice of these three categories lies my attempt to try to trace a lineage or historicity for the kerani, to find, if not an origin, a significant presence in these discursive formations. All these categories were suggested to me either by my peers or by established academics of the discipline. I am grateful to them for asking me to explore these formations. However, from what I have culled out of these analyses, our kerani remains an aberration, an uneasy presence in all possible sociocultural narratives that could possibly accommodate him. What follows in the next few chapters is an attempt to explore this ambiguity of his location. With trepidation, I will call it a cultural history of sorts, of the nineteenth-century kerani in Calcutta. I have trespassed beyond my disciplinary training, and I shall accept critiques of my attempt with humility. 


\section{References}

Advice to young civilians. (1832). The Asiatic Journal and Monthly Miscellany, 8, 187-196.

Ahmed, S.U. (1993). Nagarayan o nagariksreni. In Sirajul Islam (Ed.), Bangladesher itihas: 1704-1971 Volume 3: Samajik o sangskritik itihas (pp. 175-209). Dhaka, Bangladesh: Asiatic Society of Bangladesh.

Alam, M., \& Subrahmanyam, S. (2004). The making of a munshi. Comparative Studies of South Asia, Africa and the Middle East, 24(2), 61-72.

Alam, M., \& Subrahmanyam, S. (2010). Witnesses and agents of Empire: Eighteenthcentury historiography and the world of the Mughal munshi. Journal of the Economic and Social History of the Orient, 53, 393-423.

Attewell, P. (1989). The clerk deskilled: A study in false nostalgia. Journal of Historical Sociology, 2(4), 357-388.

Baladouni, V. (1990). Charles Lamb: A man of letters and a clerk in the accountant's department of the East India Company. The Accounting Historians Journal, 17(2), 21-36.

Bandopadhyay, H. (Ed.). (1966). Bangiya sabdakosh. New Delhi, India: Sahitya Akademi (Original work published 1933).

Banerjee, J.D. (1896). Drudgery or slavery. Calcutta, India: Reliance Press.

Banerjee, S. (1989). The parlour and the streets: Elite and popular culture in nineteenth century Calcutta. Calcutta, India: Seagull.

A Bank Clerk. (1878). The loosed interval: A holiday handbook and out-of-harness manual. London: Wyman \& Sons.

Basu, B. (Ed.). (1986). Kalikata kamalalaya and Kalikata kalpalata. Calcutta, India: Pratibhash.

Bayly, C. (1996). Empire and information: Intelligence gathering and social communication in India, 1780-1870. Cambridge: Cambridge University Press.

Beames, J. (1984). Memoirs of a Bengal civilian. New Delhi, India: Manohar (Original work published 1961).

Bellew, H.W. (1880). Memoirs of a griffin; or, a cadet's first year in India. London: W.H. Allen \& Co.

Bengal Salaries Commission. (1886). Report of the salaries commission appointed by the Government of Bengal to revise the salaries of the ministerial officers and to Reorganize the system of business in executive offices, 1885-1886. Calcutta, India: Bengal Secretariat Press.

Bhabha, H.K. (2004). The location of culture (2nd ed.). London: Routledge.

Bhadra, G. (1976). Social groups and relations in the town of Murshidabad, 17651793. In The Indian historical review. Volume II, Number I. Delhi, India: Vikas Publishing House.

Bhadra, G. (2011). Nyara battalay jaay kobar. Kolkata, India: Chhatim Books.

Bhattacharya, T. (2005). The sentinels of culture: Class, education, and the colonial intellectual in Bengal (1848-85). New Delhi, India: Oxford University Press.

Bishi, P. (2015). Carey saheber munshi. Kolkata, India: Mitra \& Ghosh (Original work published 1958).

Biswas, A., \& Acharya, A. (Eds.). (2013). Bangalir battala (Vol. 1). Kolkata, India: Anushtup. 
Biswas, S. (Ed.). (1964). Samsad Bangla ovidhan. Calcutta, India: Sishu Sahitya Samsad (Original work published in 1957).

Blechynden, K. (1978). Calcutta: Past and present (N.R. Ray, Ed.). Calcutta, India: General Publishers.

Braverman, H. (1974). Labor and monopoly capital. New York: Monthly Review.

Broomfield, J.H. (1968). Elite conflict in a plural society: 20th Century Bengal. Bombay, India: Oxford University Press.

Brown, W.J. (1943). So far . . London: Allen and Unwin.

Carey, J. (1992). The intellectuals and the masses: Pride and prejudice among the literary intelligentsia. London: Faber and Faber.

Carey, W., \& Marshman, J.C. (1828). Dictionary of the Bengali language (Vol. II). Serampore, India: The Serampore Press.

Chakrabarti, D. (2005). Colonial clerks: A social history of deprivation and domination. Kolkata, India: K.P. Bagchi and Company.

Chakrabarty, D. (1992). Postcoloniality and the artifice of history: Who speaks for 'Indian' pasts? Representations, 37, 1-26. https://doi.org/10.2307/2928652

Chakrabarty, D. (2000). Provincializing Europe: Postcolonial thought and historical difference. Princeton, NJ: Princeton University Press.

Chakrabarty, D. (2018). Monorother thikana. Kolkata, India: Anustup.

Chakrabarty, M. (1962). Kabikankan-chandi (3rd ed., S. Bandopadhyay \& B. Chaudhury, Eds.). Calcutta, India: University of Calcutta. (Original work published 1579)

Chatterjee, P. (1994). The nation and its fragments: Colonial and postcolonial histories. Delhi, India: Oxford University Press.

Chattopadhyay, B.C. (1959). Bankim racanabali (Vol. 2). Kolkata, India: Sahitya Samsad.

Chattopadhyay, S. (2011). Bengali masculinity and the national-masculine: Some conjectures for interpretation. South Asia Research, 31(3), 265-279.

Chaudhury, S. (2005). Nababi amole Murshidabad. Kolkata, India: Ananda Publishers.

Cohn, B.S. (1996). Colonialism and its forms of knowledge: The British in India. Princeton, NJ: Princeton University Press.

Das, J. (Ed.). (1917). Bangala bhasar ovidhan. Calcutta, India: Indian Publishing House.

Das, K. (1996). Inglonde bongomahila (S. Sen, Ed.). Kolkata, India: Stree (Original work published 1885).

Das, S. K. (1978). Sahibs and munshis: An account of the college of Fort William. New Delhi, India: Orion Publications.

Dasi, B. (2009). Amaar katha o onannyo rachana (S. Chattopadhyay \& N. Acharya, Eds.). Kolkata, India: Subarnarekha (Original work published 1912).

Dasi, R. (2002). Amar jiban. Kolkata, India: Dey Book Store (Original work published 1876).

Deferred annual leave. (1908, January 15). The Railway Clerk: The Official Organ of the Railway Clerks Association, 5(49), 10-11.

Devi, S. (2010). Atmakatha (G. Neogi, Ed.). Kolkata, India: Ababhash (Original work published 1913).

Dutt, R.P. (1947). India today. Bombay, India: People's Publishing House.

Dutt, S.C. (2013). Kerani jiboner rojnamcha (A. Dasgupta, Trans.). Kolkata, India: Saat Samudra (Original work published 1877). 
Editorial. (1920, February). The Woman Clerk: The Organ of the Association of Women Clerks and Secretaries, 1(3), 27.

Editorial notes. (1908, February 15). The Railway Clerk: The Official Organ of the Railway Clerks Association, 5(50), 24-25.

Edmonstone, N.B. (1841). Copy of a Personal Narrative by Neil Benjamin Edmonstone of his Indian Career and Public Service from 1783 to 1840. Small Collections (Box 9). Centre of South Asian Studies, University of Cambridge, Cambridge, UK.

Firminger, W.K. (Ed.). (1910). Bengal past and present. Volume V. January-June, 1910. Calcutta, India: Calcutta Historical Society.

Forster, E.M. (1910). Howards end. London: Edward Arnold.

Foucault, M. (1995). Discipline and punish: The birth of the prison (A. Sheridan, Trans.). New York: Vintage Books (Original work published in 1975).

Gentlemen. (1862, January-June). The Cornhill Magazine, 5, 327-343.

Ghose, B. (Ed.). (1978). Selections from English periodicals of 19th century Bengal Volume 1: 1815-33. Calcutta, India: Papyrus.

Gissing, G. (1992). The nether world. London: Oxford University Press (Original work published 1889).

Grossmith, G., \& Grossmith, W. (1999). The diary of a nobody. London: Penguin (Original work published 1892).

Hardless, C. (1889). Clerk's manual: A complete guide to general office routine. Calcutta, India: Thacker, Spink and Co.

Heller, M. (2011). London clerical workers, 1880-1914: Development of the labour market. London: Pickering \& Chatto.

Hindu clerks. (1879). Bombay, India: Family Printing Press.

Hodder, E. (1862). The junior clerk: A tale of city life. London: Jackson, Walford, and Hodder.

Houlston's Industrial Library. (1878). No. 7 the clerk: A sketch in outline of his duties and discipline. London: Houlston and Sons.

Hyde, H.B. (Ed.). (1901). Parochial annals of Bengal. Calcutta, India: Bengal Secretariat Book Depot.

Isaac Pitman and Sons (1920, February). Pitman's books for business girls [Advertisement]. The Woman Clerk: The Organ of The Association of Women Clerks and Secretaries, 1(3), 37.

Jack, J.C. (1915). Final report on the surveys and settlement operation in the district of Bakharganj, 1900-1908. Calcutta.

Joshi, S. (2001). Fractured modernity: Making of a middle class in colonial North India. New Delhi, India: Oxford University Press.

Kerani-darpan. (1874). Calcutta, India: Published by Srijukta Babu Chandicharan Ghosh.

Kerani puran: Or a true picture of a kerani, his home, health and his social status by experience. (1886). Calcutta, India: Mangalganj Mission Press.

Khan, I.A. (1975). Presidential address: The middle classes in the Mughal Empire. Proceedings of the Indian History Congress, 36, 113-141. Retrieved from www. jstor.org/stable/44138840.

Kincaid, D. (2019). British social life in India: 1608-1937. New Delhi, India: Rupa.

Kinra, R. (2015). Writing self, writing Empire: Chandar Bhan Brahman and the cultural world of the Indo-Persian state secretary. Berkeley, CA: University of California Press. 
Kipling, R. (1949). Selected prose and poetry. New York: Garden City Publishing Company.

Klingender, F.D. (1935). The condition of clerical labour in Britain. London: Martin Lawrence Ltd.

Lamb, C. (1900a). The essays of Elia. London: J. M. Dent \& Co.

Lamb, C. (1900b). Last essays of Elia. London: J. M. Dent \& Co.

Latour, B. (1993). We have never been modern (C. Porter, Trans.). Cambridge, MA: Harvard University Press.

Lewis, J.E. (1988). Women clerical workers in the late nineteenth and early twentieth centuries. In Gregory Anderson (Ed.), The white-bloused revolution; Female office workers since 1870 (pp. 27-47). Manchester: Manchester University Press.

Lockwood, D. (1989). The blackcoated worker: A study in class consciousness (2nd ed.). Oxford: Clarendon Press (Original work published 1958).

Long, J. Rev. (1862). Five hundred questions on subjects requiring investigation in the social condition of natives. Calcutta, India: Baptist Mission Press.

Long, J. Rev. (1869). Selections from unpublished records of government for the years 1748 to 1767 inclusive relating mainly to the social condition of Bengal with a map of Calcutta in 1784 (Vol. 1). Calcutta, India: Office of Superintendent of Government Printing.

Long, J. Rev. (1973). Selections from unpublished records of government for the years 1748 to 1767 inclusive relating mainly to the social condition of Bengal with a map of Calcutta in 1784 (Mahadevaprasad Saha, Ed.). Calcutta, India: Firma KLM (Original work published 1869).

Long, J. Rev., \& Stocqueler, J.H. (1983). British social life in ancient Calcutta (17501850) (P. Thankappan Nair, Ed.). Calcutta, India: Sanskrit Pustak Bhandar.

Lucas, E.V. (1968). The life of Charles Lamb (Vol. 2). New York: AMS Press Inc (Original work published 1905).

Majumdar, R.C. (1960). Glimpses of Bengal in the nineteenth century. Calcutta, India: Firma KLM.

Mallet, P. (Ed.). (2015). The Victorian novel and masculinity. Hampshire: Palgrave Macmillan.

Mill, J.S. (1848). Principles of political economy with some of their applications to social philosophy. London: John W. Parker, West Strand.

Misra, B.B. (1983). The Indian middle classes: Their growth in modern times. New Delhi: Oxford University Press (Original book published 1961).

Mitra, D. (1943). Sadhabar ekadashi (B. Bandopadhyay \& S. Das, Eds.). Calcutta, India: Bangiya Sahitya Parishat (Original work published 1866).

Mohit, M.A. (1991). History of urban growth and concentration in Dhaka: An analysis of spatial organisation of power and authority. In S. U. Ahmed (Ed.), Dhaka: Past present future (pp. 614-633). Dhaka, Bangladesh: Asiatic Society of Bangladesh.

Mohsin, K.M. (1980). Murshidabad in the eighteenth century. In K. Ballhatchet \& J. Harrison (Eds.), The city in South Asia: Pre-modern and modern (pp. 71-84a). London: Curzon Press.

Monsman, G. (1990). Charles Lamb's Elia as a clerk: The commercial employment of a literary writer. The Wordsworth Circle, 21(3), 96-100. 
Mukharji, P.B. (2009). Nationalizing the body: The medical market, print and daktari medicine. London: Anthem Press.

Mukherjee, A. (1968). Reform and regeneration in Bengal, 1774-1823. Calcutta, India: Rabindra Bharati University.

Mukherjee, S.N. (1993). Calcutta: Essays in urban history. Calcutta, India: Subarnarekha.

Nag, A. (Ed.). (2008). Sotik hutom pyanchar noksha. Kolkata, India: Ananda Publishers (Original work published 1862).

Nandy, A. (2009). The intimate enemy: Loss and recovery of self under colonialism (2nd ed.). New Delhi, India: Oxford University Press.

Nixon, N. (2019). Debating the 'after' of subaltern studies. Economic and Political Weekly, 54(29), 27-31.

The Noiseless Typewriter Co. (1920, February).[Advertisement for demonstration of a typewriter]. The Woman Clerk: The Organ of the Association of Women Clerks and Secretaries, 1(4), 36.

'Off the track' in London: Being actual experiences in a hunt after employment. (1878). London: 'Labour News'.

Parsons, C.E. (1876). Clerks: Their position and advancement. London: Provost and Co.

Pickard, O. G. (1950). Clerical trade unions and education for office work. The Vocational Aspect of Secondary and Further Education, 2(4), 101-111.

The railway clerk: Where will he stand tomorrow? (1908, May 15). The Railway Clerk: The Official Organ of the Railway Clerks Association, 5(53), 69.

Raman, B. (2012). Document raj: Writing and scribes in early colonial South India. Chicago, IL: The University of Chicago Press.

Ray, B. (2002/2010). Joto beshi jaane toto beshi mane. In Joto beshi jaane toto beshi maane: Ekantobaadi sahityo samalochona birodhee prostaab (pp. 13-23). Kolkata, India: Deys Publishing.

Rose, J. (2010). The intellectual life of the British working classes (2nd ed.). New Haven, CT: Yale University Press.

Saha, A. (Ed.). (1999). Dusprapyo bangla sabitya. Kolkata, India: Saptarshi Prakashan. Sarkar, D. (1982). Pal-Sen juger bongsanucharit. Calcutta, India: Sahityolok.

Sarkar, S. (1997/2005). Writing social history. New Delhi, India: Oxford University Press.

Sarkar, T. (2013). Hindu wife, Hindu nation: Community, religion and cultural nationalism. Delhi, India: Permanent Black (Original work published 2001).

Sen, R.C. (1834). Dictionary in English and Bengalee (Vol. 1). Serampore, India: The Serampore Press.

Sil, N.P. (2017). Problem child of renascent Bengal: The babu of colonial Calcutta. Kolkata, India: K.P. Bagchi and Company.

Sinha, N.K. (1970). The economic history of Bengal (Vol. 3). Calcutta, India: Firma KLM.

Sinha, N.K. (1981-1985). The economic history of Bengal (2nd ed., Vols. 1-3). Calcutta, India: Firma KLM.

Sinha, P. (1967). Social changes. In N.K. Sinha (Ed.), The history of Bengal (17571905) (pp. 384-428). Calcutta, India: University of Calcutta.

Smiles, S. (1859). Self-help; With illustrations of character and conduct. Retrieved from https://oll.libertyfund.org/titles/smiles-self-help-with-illustrations-of-characterand-conduct 
Smith, G. (1879). The life of Alexander Duff D.D., L.L.D. Volume 1. London: Hodder and Stoughton.

Spear, P. (1980). The nabobs: A study of the social life of the English in eighteenth century India. London: Curzon Press (Original work published 1932).

Spear, P. (n.d.). English social life in India a hundred years ago. Spear, T. G. P. Papers (Box 46. Folder 1). Centre of South Asian Studies, University of Cambridge, Cambridge, UK.

Sreemani, S. (1994). Anatomy of a colonial town Calcutta, 1756-1794. Calcutta, India: Firma KLM.

Sreepantho. (2012). Kolkata. Kolkata, India: Ananda Publishers (Original work published 1999).

The story of a London clerk: A faithful narrative faithfully told. (1896). London: The Leadenhall Press Ltd.

Sur, N. (2019). Sayebmem samachar: Kompanir amole Kolkata. Kolkata, India: Ananda Publishers.

Tagore, R. (2013). Relationships (S. Chaudhuri, Trans.). New Delhi, India: Oxford University Press (Original work published 1929).

Tickell, A. (Ed.). (2005). Selections from 'Bengaliana'. Nottingham: Trent Editions.

Viswanathan, G. (2004). Masks of conquest: Literary study and British rule in India. New Delhi, India: Oxford University Press.

Wild, J. (2006). The rise of the office clerk in literary culture, 1880-1939. New York: Palgrave Macmillan.

The young clerk's manual or counting-house assistant. (1846). London: Cradock and Co.

Yule, H., Burnell, A.C., \& Crooke, W. (1903). Hobson-Jobson: A glossary of colloquial Anglo-Indian words and phrases, and of kindred terms, etymological, historical, geographical and discursive. London: J. Murray. 